\title{
MILESTONES IN BALTIC STUDIES IN MOSCOW ${ }^{1}$
}

\author{
Maria Zavyalova \\ Institute of Slavic Studies, Russian Academy of Sciences, Moscow, Russia \\ e-mail:mariazavyalova@gmail.com
}

\begin{abstract}
The article describes the history of research on Baltic languages in Moscow from the second half of the $19^{\text {th }}$ century, when the Lithuanian language began to be taught at Moscow University. At different times, the Moscow State University, the Institute of Slavic Studies of the Russian Academy of Sciences, the "Baltrušaitis House" at the Embassy of the Republic of Lithuania in the Russian Federation, and the Institute of Linguistics of the Russian Academy of Sciences were the centers of research on Baltic studies in Moscow.

The article describes the main directions in development of Balto-Slavic studies in Moscow, gives the names of prominent scholars in this field and provides a bibliography of the major publications.
\end{abstract}

Keywords: Balto-Slavic studies, Embassy of the Republic of Lithuania in the Russian Federation, Institute of Slavic Studies, Lithuanian language, Moscow State University, Russian Academy of Sciences

\section{First Period: Moscow University (1860s - 1950s)}

Baltic studies in Moscow developed as a linguistic specialization during the second half of the $19^{\text {th }}$ century. In different periods, the centers where the main scientific research was concentrated were various research and academic institutions. Moscow University was the first to launch these studies. For a long 
time, the course of the Lithuanian language was taught in the framework of the comparative historical grammar of the Indo-European languages.

The basis for the development of Baltic studies in Moscow was the Department of Comparative Grammar of Indo-European Languages, opened in 1863. The department was commissioned by Pavel Ya. Petrov, he was a Sanskrit specialist, but did not specifically deal with the comparative grammar of IndoEuropean languages. In the comments on the history of the Greek and Latin languages, Petrov often delivered lectures on the Lithuanian language. One of the students who attended the lecture of P.Ya. Petrov, was Filipp F. Fortunatov, who showed great interest in comparative historical linguistics.

F.F. Fortunatov entered the university a year after the foundation of a new department (in 1864), studying linguistics independently. In Lithuanian studies, an important role also played the possibility of direct communication with native speakers within the university: there were many Lithuanian and Latvian students at the philological department of Moscow State University. One Lithuanian student, Andrius Botyrius, was a friend of Fortunatov and Vsevolod F. Miller (an Iranian expert and an Indo-Europeanist). After graduating from the university in 1871, Fortunatov and Miller came to Botyrius for summer vacations. One particular trip turned out to be decisive in the fate of Moscow Baltic studies. For about a month, Miller and Fortunatov lived in the village of their friend's father and recorded Lithuanian folk songs, which they later published (Miller \& Fortunatov 1873). It was then that they became interested in dialectology: they were struck by the deviations of the local dialect from the literary language. The richness of folklore fascinated the researchers and they began to record songs, tales, and proverbs, with the exact observance of the peculiarities of the dialect. The observations made during a trip to Lithuania led Fortunatov to many theoretical conclusions: he was the first to consider language not as something monolithic, broken up into dialects, but as a primordial set of dialects, which was confirmed by later research. Many of Fortunatov's theoretical conclusions appeared precisely in contact with specific dialects of modern languages. These studies marked a new approach to the analysis of linguistic material: in the early 1870s, the transition from atomism in comparative historical linguistics to an attempt to synthesize begins, there was an interest in living language, dialect, folklore, and text as such. This approach was reflected in the nature of the research itself: Fortunatov's students said that each lesson he began with the denial of what he said yesterday, and 
each time he proposed a new, stronger option than he had given at previous lectures. Fortunatov did not write a single book on the Baltic languages, but he made a great contribution to Baltic studies. He was interested in the most complex problems - accentology, intonation - we recall his law on intonationdependent stress shift (made simultaneously with Saussure), he was the first in Russia to study the Prussian language.

F.F. Fortunatov was the head of the department of comparative grammar of Indo-European languages until his departure to St. Petersburg in 1902. All this time, among other courses, he taught Lithuanian as well. His merit lies not only in the fact that his activities laid the foundation for the development of Baltic studies in Moscow, but also in the fact that "he created a system of teaching linguistic disciplines at Moscow University" (Peterson 1946: 27), i.e. essentially created not only the Baltic, but also the linguistic school at Moscow. After Fortunatov was elected a full-time ordinary academician in the department of Russian language and literature, he was forced to move to St. Petersburg. Moving to St. Petersburg opened a new stage in the life of the academician. Petersburg life was more saturated with communication with the Lithuanians, and new interesting contacts awaited him, in particular, with a very competent Lithuanist of that time Kazimieras Jaunius.

The work initiated by F.F. Fortunatov, was continued by his followers. His students were subsequently famous scientists Aleksej A. Shakhmatov, Dmitrij N. Ushakov, Grigorij K. Ulyanov, Nikolaj N. Durnovo, Mikhail M. Pokrovsky, Viacheslav N. Shchepkin et al. Fortunatov's students were interested in different areas of linguistics, but many of them showed echoes of Lithuanian language studies. For example, Grigorij O. Vinokur - a talented linguist, literary historian, folklorist, wrote a work on Lithuanian versification. According to Vladimir N. Toporov, if it had been published in the 1920s, it would have become the seminal analysis of the Lithuanian metric.

The main successor to F.F. Fortunatov at Moscow University became Viktor K. Porzhezinsky, who headed the department of Comparative Historical Linguistics after him. His main works, which are written in the history of Moscow Baltic studies, are two books on the Baltic verb (Porzhezinsky 1901; 1903). V.K. Porzhezinsky managed to organize a special linguistic department at Moscow University, which, however, was closed in 1913. This department, despite the short duration of its existence, played a large role in the development of Russian linguistics. 
Among the first who studied at this department was Mikhail N. Peterson. Unfortunately, after the revolution and the end of the Civil War in 1921, Porzhezinsky was forced to leave for Poland, where he continued to teach comparative historical linguistics. After his departure, classes in the Lithuanian language at the university were only possible until 1925: all this time, he was privately taught by M.N. Peterson. The year 1925 marked the beginning of the "dark period" in the history of Moscow linguistics.

Soon, as a result of the "new trends" in linguistics, all classes at the faculty were canceled. In the 1930s, the faculty was dissolved, and the faculty of social studies appeared in its place. In protest M.N. Peterson went to the Institute of Meteorology. When in 1935 the Institute of Philosophy, Literature and History was organized, he moved to work there. Despite the sociological bias that dominated linguistics in those years, Peterson remained loyal to his scientific position, which was probably not easy. This is evidenced by an extract from the materials of one of the meetings held in 1948: "Professor M.N. Peterson continues to defend his formalistic views in the field of syntax, he did not abandon his politically harmful view of the need to introduce the main methodological principles of the Fortunatov school into Soviet linguistics" (Lomtev 1948: 39). Also in 1948, Peterson managed to publish an article dedicated to the $400^{\text {th }}$ anniversary of the book of Martynas Mažvydas (Peterson 1948). This was the first mention of the name of Mažvydas and his book in Russian Baltic studies.

\section{Second Period: Institute of Slavic Studies (1950s - 1990s)}

The break in the lessons of the Lithuanian language at the university lasted until 1947. Since 1946, first-year students of the Faculty of Philology Tatiana V. Bulygina, Pavel A. Grinzer, Tatiana Ya. Elizarenkova, Viacheslav Vs. Ivanov, Vladimir N. Toporov, Sergej S. Tselnicker began to study Sanskrit with M.N. Peterson. Not all of these friends had the patience to finish these classes, but joint communication played an important role in their future scientific life. Then Sanskrit texts were studied, Peterson gave a comparatively historical commentary, mostly lexical, very often citing Lithuanian examples. He constantly referred to the opinion of Antoine Meillet that the modern Lithuanian language is at the level of its development at the same stage at which Latin was in the $3^{\text {rd }}$ century. BC. - i.e. it is the oldest of modern Indo-European languages, which in the process of changing the grammatical system did not destroy, but 
transformed, the ancient heritage. These facts aroused students' interest in the Lithuanian language, and at their request the following year Peterson began to teach a course in Lithuanian. However, only V.N. Toporov and T.Ya. Elizarenkova attended this course up to the end.

Again, as almost a century ago, in the case of F.F. Fortunatov, contacts with native speakers played a decisive role - after graduating from university, V.N. Toporov, T.Ya. Elizarenkova and T.V. Bulygina went to Lithuania for the summer and there met Kostas Korsakas, Director of the Institute of Lithuanian Language and Literature. In 1951, Toporov entered the graduate school of Moscow State University simultaneously with Vytautas Mažiulis, who later became a prominent Lithuanian scientist, author of the etymological dictionary of the Prussian language. Later, in 1954, Toporov met with Zigmas Zinkevičius, in 1955 with Algirdas Sabaliauskas, and these friendly, and later scientific contacts played a big role in his scientific work. Toporov repeatedly emphasized that communication with Lithuania and Lithuanians was always of great importance for him, that he constantly received great support from Lithuanian colleagues and friends.

We can say that from the moment when V.N. Toporov began his postgraduate studies, a new period opened in the history of Moscow Baltic studies. Samuil B. Bernstein, who became his scientific adviser, was very pleased that Toporov knew the Lithuanian language, and offered him a topic - Balto-Slavic language relations. This topic subsequently became one of the leading ones at the Institute of Slavic Studies, where Toporov came soon after graduating from postgraduate course. V.N. Toporov began his scientific career in Baltic studies with two works: the etymology of four Prussian words (Toporov 1958) ${ }^{2}$ and a review of the state of Baltic studies in the post-war period (Toporov 1959).

The Institute of Slavic Studies (from 1968 to 1997 - Institute of Slavic and Balkan Studies) was destined to become the second center of Baltic studies after Moscow University in Moscow. At the Fourth Congress of Slavists, which was held in 1958 in Moscow, the hypothesis of Viach.Vs. Ivanov and V.N. Toporov about the Balto-Slavic relations was identified as a new ethnogenetic problem (Ivanov \& Toporov 1958). The report delivered at this congress for the first time raised the question of the need for a theoretical approach to the ancient relations of the Baltic and Slavic languages, and not just listing the similarities and differences, as has been done so far. The authors understood the ancient state not as a traditional proto-language, but as a spatio-temporal continuum 
of dialects. Based on the identity of the models reconstructed for the most ancient Baltic and Slavic state, the authors came to the conclusion that it was worthwhile "to consider the model established for the Slavic as the result of the transformation of the model established for the oldest Baltic state" (Ivanov \& Toporov 1958: 39). As one of the arguments, they cited primarily the exceptional dialectal fragmentation of the Baltic language region with the compactness of the territory and the weak differentiation of the Slavic region with its greater territorial extent. This pioneering work turned over previous ideas about the nature of Balto-Slavic relations and largely determined the nature of further research in this area.

Soon the topic of Balto-Slavic studies was singled out as a separate research area of the Institute. This happened at a conference on topical issues of Slavic studies, initiated by former V.N. Toporov's scientific adviser S.B. Bernstein. In 1960, the Institute formed the sector of the structural typology of Slavic languages, and Baltic studies immediately took prominent place in it. Soon the sector was headed by Viach.Vs. Ivanov, who had come to the Institute in 1961. Ivanov, who, like his colleagues at the university, began his career in Baltic studies with native speakers' personal contacts. Viach.Vs. Ivanov first came to Latvia in 1946, and in 1947 spent two months at the Writers' Creative House in Dubulti. Then he began to learn the Latvian language, met Mirdza Kempe and started to translate poems by Latvian poets. In 1953, Ivanov again lived in Dubulti for a long time. He studied, in addition to Latvian, the Libyan language. He twice went to Jānis Endzelīns in his estate "Naka". It should be noted that V.N. Toporov began to study the Latvian language at the Riga seaside, where he first arrived with T.Ya. Elizarenkova in $1949^{3}$.

In the 1960s, articles on Baltic studies began to appear in various periodicals of the Institute, such as "Brief Communications of the Institute of Slavic Studies", "Soviet Slavic Studies", "Issues of Slavic Linguistics", and "Scientific Notes of the Institute of Slavic Studies". The topic of Balto-Slavic relations repeatedly arises during this period in articles by Vladimir A. Dybo (Dybo 1961; 1962), Viacheslav Vs. Ivanov (Ivanov 1958; 1964), Vladislav M. Illich-Svitych (IllichSvitych 1961; 1962), Vladimir N. Toporov (Toporov 1958a; 1961; 1961a; 1961b; 1962).

In his article "On the Problem of Balto-Slavic Linguistic Relations" (Toporov 1961b) V.N. Toporov identified the main tasks of the Balto-Slavic problems: this is, first of all, identification of the peculiarities of dialectal fragmentation 
of the Baltic language region and the predominant connections of individual dialectal areas with each other and with other Indo-European regions; revealing the nature of the Baltic dialects that once covered the territory of northern Belarus, Lithuania and partly Latvia from the west, south and east; the task of hydronymic stratification of the alleged Baltic territories; research in the field of Baltic lexical borrowings in Russian dialect vocabulary; the study of common motives in folklore, in particular ritual and religious beliefs; the study of typical isogloss outside areas for which the Baltic-speaking population can be assumed (Pannonia, Balkans, Adriatic); the study of the area at the junction of the Baltic and Slavic worlds, in which the features characteristic of the "language union" are manifested. For the first time, the study of the Balto-Slavic problem was presented as a comprehensive study. The outlined tasks, then only mapped down, became the starting point for the research of the Moscow Baltists - some were successfully implemented, others are in the process of being studied, some remained in the plans.

The first undertaking was the dialectological expeditions carried out since 1962. The staff of the Institute Margarita I. Lekomtseva, Lidija G. Nevskaya, Tamara M. Sudnik, Vladimir N. Toporov, Tatiana V. Tsivyan, Svetlana M. Shur (Tolstaya) participated in them together with employees of the dialectology sector of the Institute of Lithuanian Language and Literature in Vilnius. In 1964, the Conference "Problems of Linguistic and Ethnography and Areal Dialectology" was held at the Institute of Slavic Studies, at which a report was made by T.M. Sudnik, V.N. Toporov and S.M. Shur about the southern part of the Balto-Slavic language union (later the report was published as an article in "Soviet Slavic Studies" (Sudnik \& Tolstaya \& Toporov 1967)).

This approach to the areal Balto-Slavic contacts, based on the concept of a linguistic union, became the starting point for further research. For many years (mainly the 1960s and 1970s), a large volume of dialectological material was collected, then summarized in T.M. Sudnik and L.G. Nevskaya books (Sudnik 1975; Nevskaya 1977).

Thus, the first relevant direction in Moscow Baltic studies was the study of the Balto-Slavic area as a language union, and the basis of the research (as at the end of the last century for F.F. Fortunatov) was living dialect material. Many researchers began their acquaintance with folklore precisely from this material, and this subsequently determined another area of Moscow research in the field of Baltic studies. 
At the same time, other directions in the study of the Balto-Slavic problems are outlined, which later became important milestones in the development of the Moscow Baltic studies: this is accentology (V. A. Dybo, V. M. Illich-Svitych); etymology (Viach.Vs. Ivanov, V.N. Toporov); linguogeography (Ruf’ A. Ageeva, V.N. Toporov, Oleg N. Trubachev). Three major works that became classical in Balto-Slavic linguistics belong to the 1960s: (Toporov \& Trubachev 1962; Illich-Svitych 1963; Ivanov \& Toporov 1965). The latter laid the foundation for a series of semiotic studies in the field of Balto-Slavic antiquities.

The doctoral dissertation defended by Viach.Vs. Ivanov in 1979 was dedicated to the Baltic and Slavic verb ("Reflection of Two Series of Indo-European Verb Forms in the Baltic and Slavic"); later his monograph on the same subject was published (Ivanov 1981).

These studies soon became one of the central areas of Baltic studies at the Institute of Slavic Studies, replacing dialectological studies, the result of which was a comprehensive report by T.M. Sudnik and L.G. Nevskaya at the Congress of Slavists in 1978 (Nevskaya \& Sudnik 1978). Similar works appeared in the future, however, in general, there was a reorientation into the sphere of spiritual culture and folklore texts.

The next important stage in the history of Moscow Baltic studies was the launch of a collection of "Balto-Slavic Studies". At the first Balto-Slavic conference "Ethnolinguistic Balto-Slavic Contacts in the Present and in the Past" held in 1978, the question was raised for the first time about a periodical devoted to Balto-Slavic problems. At the same conference, a circle of future authors of the collection began to form. At first it was decided to publish a serial collection called Balto-Balcanica, in which the Baltic and Balkan issues would alternate as two main areas, but this decision was not approved by the directorate. After many troubles, only at the end of 1979 a resolution was adopted by the Presidium of the USSR Academy of Sciences on the establishment of the annual "Balto-Slavic Studies". This series edition was preceded by three collections: "Balto-Slavic Collection" (1972), "Balto-Slavic Studies" (1974), "Balto-Slavic Ethnic-Language Contacts” (1980).

The periodical collection "Balto-Slavic Studies" was launched in 1981. Each volume published was issued without the assurance that it was not the last, since the publication was always associated with many difficulties. However, thanks to the efforts of members of the editorial board with Viach.Vs. Ivanov, the editor-in-chief, and the huge work of the permanent secretary of the editions 
T.M. Sudnik, who was in charge to prepare the manuscripts of all issues to be published, "Balto-Slavic Studies" appeared almost every year (until 19894). Almost all issues were dedicated to various events: these were conference materials, memorable dates and anniversaries (such as the anniversary of Vilnius in 1983). The first issue outlines the tasks of the collection: comparative historical grammar of the Baltic and Slavic languages; research of contacts of the Baltic and Slavic languages and cultures in their present and past; comparative typological study of the Baltic and Slavic languages and cultures; study of the Indo-European basis of the Balto-Slavic problems; problems of ethnogenesis of the Balts and Slavs based on the material of language, toponymy and onomastics, spiritual and material culture (Ivanov 1981).

Studies at the junction of the Baltic and Slavic worlds seemed relevant not only as an internal problem of their ethnogenesis and development, but also as a basis for the study of many theoretical problems. Prominent scientists from Russia, Lithuania, Latvia, Poland, and Germany took part in the collection. Many breakthrough ideas first saw the these editions, for example, an article by Z. Zinkevičius on the Yotvingian dictionary was published in the Balto-Slavic Studies earlier than in "Baltistica" in Lithuania (Zinkevichus 1984). Almost all the investigations of V.N. Toporov on establishing the boundaries of the settlement of ancient Balts in modern Slavic territories were published in this collection (Toporov 1982; 1988; 1989). These articles establish the Baltic character of almost 300 hydronyms belonging to the basins of the Moscow, Oka, Klyazma and Volga rivers, and thus resolve the issue of the Eastern border of the Baltic hydronymic range.

Direction of linguistic geography developed in the works of V.N. Toporov and other linguists, was most fully developed in collaboration with historians and archaeologists. Starting from the second Balto-Slavic conference, which was held in 1983 under the name "Balto-Slavic Ethnolinguistic Relations in the Historical and Areal Plan", Balto-Slavic studies successfully combined linguistic and historical approaches. Historians and archaeologists (Vera I. Matuzova, Vladimir I. Kulakov, Jerzy Ochmański, Valentin V. Sedov) sought to take into account linguistic data in their works; linguists, in turn, tried to rely on new archaeological research. Such an interdisciplinary approach is perhaps a distinctive feature and, undoubtedly, one of the strengths of the Moscow Baltic school. Another important topic requiring an exclusively interdisciplinary approach, bringing together not only historians and linguists, but also cultural experts, is 
the problem of the Grand Duchy of Lithuania. This topic has been repeatedly discussed in the works of Moscow Baltists, but so far, unfortunately, has not been developed as a separate area of comprehensive research.

However, in another area - spiritual culture, interaction with historians was very fruitful. In 1985, the conference "Balto-Slavic Ethnocultural and Archaeological Antiquities. Funeral Rite", became the second in a series of conferences devoted to problems of the text (the first symposium on the structure of the text was held in 1979). The conference "Ethnolinguistics of the Text. The Semiotics of Small Forms of Folklore was held in 1988. These conferences preceded a series of collections that appeared already in the 1990s under the general title "Studies in the Field of Balto-Slavic Spiritual Culture" (Ivanov et al. (eds.) 1990; Nikolaeva (ed.) 1993; Nikolaeva (ed.) 1994-1999).

In addition to these conferences, two conferences should be noted, they symbolized attempts to go beyond the Balto-Slavic area, to include the problems of Balto-Slavic contacts in a wider context. This is a conference held in 1990 on the Baltic-Finnish areal problems "Uralo-Indo-Germanica" (its materials are published in "Balto-Slavic Studies-96"), and the already mentioned text structure symposium, under the title "Balcano-Balto-Slavica. Symposium on the Structure of the Text”. Baltic-Balkan problems are another promising topic that has been outlined in the works of scientists of the Institute, but has not yet received wide development. The works devoted to this subject were also published in the collection "Balto-Slavic Studies" (Sudnik \& Tsivyan 1981; 1982; Tsivyan 1989). The last major multidisciplinary work was devoted to the notion of the path in the Baltic-Balkan perspective and was presented at the Slavic Congress in Krakow in 1998 (Nevskaya \& Nikolaeva \& Sedakova \& Tsivyan 1998).

An important feature of the Balto-Slavic studies of this period is that Baltics and Balto-Slavic relations are widely understood - this is not only linguistics, synchronous, diachronic, comparative historical issues, but also specific features in the oral literature, folklore. Semiotic trend got a special attention in the activities of the department, and in the Baltic studies in particular. It allowed to combine different genres of folklore and later texts and to reconstruct the deepest meanings on their basis, which assisted innovative investigations in the field of spiritual culture of the Balts and Slavs and search for parallels with other traditions. 
It should be noted that there was a center of Baltic studies that existed all this time in Moscow independently from the Institute of Slavic Studies. This center was part of the Institute of Linguistics, in which there were working T.V. Bulygina, who devoted many works to the problems of the grammar of the Lithuanian language (Bulygina 1970; 1977), and academician Yurij S. Stepanov, who taught at the Moscow State University the course of the Lithuanian language in comparative historical coverage ${ }^{5}$. Many Lithuanian scholars who have long and fruitfully worked in Lithuanian institutes began their academic career with Lithuanian studies precisely in Moscow under the leadership of Yu.S. Stepanov. Yu.S. Stepanov's academic school was a solid theoretical foundation that allowed his students to continue their studies more productively. The theoretical basis of the problems of Lithuanian studies is presented in many works by Stepanov. The range of topics addressed in his works is very wide - this is the verb system of the Lithuanian language, accentology, syntax in comparative historical coverage. Stepanov formulated and investigated in detail many important theoretical problems of Lithuanian linguistics: the question of the nature of the stress shift (Stepanov 1972; 1997); correlation between the verb form in the Slavic languages and the diathesis in the Baltic (Stepanov 1976-1977; 1978) etc.

Velta E. Staltmane, who taught Latvian at the Society of Latvian Culture Fellows, later at MGIMO University, at the Diplomatic Academy, was an employee of the Institute of Linguistics of the Russian Academy of Sciences. T.V. Bulygina, V.N. Toporov, V.E. Staltmane and Antons Breidaks wrote the volume "Baltic Languages" in the series "Languages of the World" (Kibrik et al. (eds.) 2006). Unfortunately, the preparation of the volume has taken a long time, and in the process of writing it T.V. Bulygina, the author of the article on Lithuanian language, and A. Breidak, who prepared an article on Latgalian language, died. An article on the Lithuanian language was added by Olga V. Sineva, an article about Latgalian - by Lidija Leikuma. The volume was released only in 2006, after the death of his chief editor and author of the article on the Prussian language V.N. Toporov. 


\section{Third Period: Embassy of Lithuania (1990s -)}

For a number of external reasons, relations between scientists from the two countries - Russia and Lithuania were lost, and, by the beginning of the 1990s, academic work in the field of Baltic studies lost its intensity: conferences ceased to be held, and the release of "Balto-Slavic Studies" was temporarily stopped (the collection was not published from 1989 to 1998). However, the Baltic issues continued to interest scientists of the Institute of Slavic Studies. From the end of the 1990s to the present, three dissertations on Baltic studies were defended in the typology and comparative linguistics department (which was headed by Tatiana M. Nikolaeva from 1990 to 2012): Maria V. Zavyalova (Zavyalova 2006) (supervisor - L.G. Nevskaya), Peter M. Arkadiev (Arkadiev 2006) (supervisors - V.N. Toporov and T.M. Nikolaeva), Kirill A. Kozhanov (Kozhanov 2015) (supervisor - P.M. Arkadiev).

However, the main activity in Baltic studies in Moscow has shifted to another center: thanks to the cooperation of scientists from the Institute of Slavic Studies of the Russian Academy of Sciences (primarily V.N. Toporov) with the cultural attaché of the Lithuanian Embassy in Russia, Juozas Budraitis, the Embassy of Lithuania ("Baltrušaitis House") has become a kind of Baltic center in Moscow for many years. The figure of the poet and diplomat Jurgis Baltrušaitis fits perfectly the role of a symbol of Russian-Lithuanian cultural ties. This house was also destined to become one of the centers uniting the two countries. It has actually always been a hotbed of Lithuanian culture in Moscow: as early as in 1989, at the very beginning of perestroika, there were created Lithuanian language courses at which Nikolaj A. Mikhailov taught, later he became a famous scholar in the field of Slavic and Baltic studies.

Since the designating of the cultural attaché J. Budraitis in 1995, this house has actually begun to function as a Lithuanian cultural center. With the help of J. Budraitis, the almost lost ties of Russian scholaers with the Baltic states of other countries were revived - not only with Lithuania and Latvia, but also others. From 1998 to 2010, thanks to such cooperation between the Lithuanian Embassy and Russian scientists, 20 conferences were held. The conferences were attended by members of the Institute of Slavic Studies of the Russian Academy of Sciences, the Institute of World Culture of Moscow State University, the Institute of General History of the Russian Academy of Sciences, Institute of World Literature of the Russian Academy of Sciences: for example, the literary 
critic Nikolaj V. Kotrelev stood at the origins of a series of conferences devoted to the poetry of J. Baltrušaitis; historian Evgeniya L. Nazarova took a large part in organizing a series of conferences dedicated to the Grand Duchy of Lithuania. This activity began in 1998 with the first major conference dedicated to Martynas Mažvydas and the first Lithuanian printed book ${ }^{6}$. Later, the cycles of conferences were designated: "Readings of Jurgis Baltrušaitis"; "The Legacy of the Grand Duchy of Lithuania"; "Baltic Crossroads". The geography of conference participants expanded: they arrived to Moscow not only from Russia, Lithuania, Latvia, Belarus, but also from Austria, Hungary, Germany, Italy, Poland, USA, Ukraine, France, Czech Republic, Estonia, and Japan. The broadest and most important problems of modern science were discussed. A distinctive feature of the conferences has always been interdisciplinarity: scientists from various countries engaged in different fields of science found a common language. After the main part of the conferences, "round tables" with interesting discussions were often organized. For example, in the framework of the conference "Ethnocultural and Linguistic Contacts on the Territory of the Grand Duchy of Lithuania", a round-table discussion "Friends or Strangers? Lithuania in Russia and Russia in Lithuania. Multiculturalism in the Modern World" was held. In the framework of the conference "Lithuania of the Mindaugas Era and its Neighbors: Historical and Cultural Ties and Parallels", a round table "The Grand Duchy of Lithuania and Kievan Rus': Who are the Heirs of these States - Lithuanians, Belarusians, Ukrainians or Russians?" was organized. The materials of many conferences were later published in the form of collections of articles, it is also a considerable accomplishment of J. Budraitis (Temchin (ed.) 2005; Budraitis et al. (eds.) 2007; Nazarova (ed.) 2007; Ivanov (ed.) 2010).

Unfortunately, after the departure of J. Budraitis, the tradition of holding conferences began to weaken. The cycle of commemorative conferences dedicated to V.N. Toporov, discontinued. From 2006 to 2009, four conferences from this cycle were held (Tsivyan et al. (eds.) 2010). From 2009 to 2012, there were no conferences in the Baltrušaitis House, but in 2011, together with Vilnius University and the Seimas of the Republic of Lithuania in Vilnius, a conference on the memory of V.N. Toporov was organized (Judžentis et al. (eds.) 2014). From 2012 to 2018, thanks to the efforts of the cultural attaché Faustas Latenas (2012), Aleksandras Šimelis (2013-2017) and Inga Vidugirytė-Pakeriené (2018-2020), seven conferences were held. A conference of 2018 shortly 
after the death of Viach.Vs. Ivanov, was dedicated to the memory of Viach. Vs. Ivanov and V.N. Toporov. In the last year of Budraitis's residency in Moscow a significant event took place - on June 16, 2009, the Institute of Slavic Studies officially opened the Center for Balto-Slavic Studies, which de facto existed for almost 50 years. The head of the Center was Viach.Vs. Ivanov (after his death in 2017 - T.V. Tsivyan). The center's first undertaking was the international conference "Modern Approaches to Baltic Linguistics", organized in October 2009 (see conference materials: Arkadiev et al. (eds.) 2015).

In 2019, the conference "Balto-Slavic Territory through the Prism of Language and Literature" combined the "Baltrušaitis House" and the Institute of Slavic Studies of the Russian Academy of Sciences. The conference was dedicated to the 10th anniversary of the Balto-Slavic Studies Center and the $90^{\text {th }}$ anniversary of Viach.Vs. Ivanov. I would like to believe that this conference will continue the tradition of Baltic conferences, which was established in the 1970s at the Institute of Slavic Studies and continued in the 1990-2000s at the "Baltrušaitis House".

In the last decade, the Baltic area has become more active in Moscow universities: in 2008, the Baltic Studies Center was opened at Moscow State University (supervisor O.V. Sineva), the Lithuanian language is taught at the Russian State Humanitarian University (teachers P.M. Arkadiev, Igor B. Tulchinsky).

So, we can distinguish the main directions of Moscow Baltic studies, identified in the last 60 years:

1) theoretical aspects of the grammar of the Lithuanian language (especially morphology, accentology, syntax) in the comparative historical and typological aspect;

2) dialectology, the study of phonetics and vocabulary of island dialects in the territory of Belarus and in the border territories of Lithuania; interaction of language systems; the study of the Balto-Slavic language union;

3) etymology, Lithuanian within the framework of Indo-European studies; attraction of the linguistic facts of the Lithuanian language for the reconstruction of the Pre-Slavic state and Indo-European models; comparative studies;

4) linguistic geography; the study of toponymy and the definition of ancient areas of resettlement of the Balts in the territories later settled by the Slavs; 
5) research in the field of text structure; semiotic approach to the text; study of the Baltic spiritual culture according to folklore texts.

Other achievements of Baltic studies, which can be attributed to the high level of scientific discoveries deserve mentionioning here:

- first of all, this is the well-grounded Viach.Vs. Ivanov and V.N. Toporov thesis regarding the origin of the Proto-Slavic language from the peripheral Baltic dialect;

- the designation of the boundaries of the present Slavic territories, which in ancient times were occupied by the Balts;

- formulation and detailed description of the complex phenomenon of the Balto-Slavic language union;

- reconstruction, on the fundamental of the Baltic and Slavic folklore material, of the basic Indo-European myth.

These achievements correspond to the main directions of the Moscow Baltic studies which emerged back in the 60s, and were an important basis for further investigation in the same areas and, possibly, the development of new research avenues.

As has been repeatedly emphasized above, an important aspect of the Moscow Baltic school is its interdisciplinarity. This wide scope manifested itself at all stages of its existence, and was notably and clearly expressed in the works of its main luminaries - Viach.Vs. Ivanov and V.N. Toporov, academicians with a unique encyclopedic scope of interests and knowledge. We hope that new generations of Moscow Baltists will further elaborate these theses through a rigorous approach to academic studies.

\section{Acknowledgements}

I am very grateful to Lidiya G. Nevskaya, Yurij S. Stepanov, Tamara M. Sudnik and Vladimir N. Toporov who helped me a lot in preparing the text, sharing their memories and materials in the 2000s. I also thank Tatiana V. Tsivyan for significant corrections and comments. 


\section{Notes}

1 This review does not pretend to be an exhaustive description of the issue, as well as to the completeness of the bibliography presented in the article.

2 Later, this topic resulted in a 5-volume dictionary of the Prussian language (A - L), which, unfortunately, was not completed (Toporov 1975-1990). In the archive of V.N. Toporov, after his death, we discovered a handwritten card index of the dictionary from the letter $\mathrm{M}$ to the end of the alphabet. An international group of scientists led by Viach. Vs. Ivanov took up the processing of this handwritten card index. The digitization and decryption of the cards was entrusted to specialists of the Lithuanian Language Institute in Vilnius. Currently, an electronic version of the card index is located at this institute.

3 For V.N. Toporov, a visit to Latvia and Lithuania in the post-war years was also an important experience regarding the formation of his political views: the situation in these places and his acquaintance with the peoples of these countries determined his deepest guilt towards Latvians and Lithuanians until the end of his life. He wrote to them: "Forgive us for all that we voluntarily or involuntarily, by our irresponsibility or by the will of the demonic forces in whose hands we were just a silent instrument, did to you; for injustice, lies, violence; for the fact that we were not able to take a historic chance to find a way to your heart and your mind, neither in the two centuries of your stay in the Russian Empire, nor in the last half century. You are a reproach to our conscience, but also our hope and a high example of genuine creative responsibility for the history of our people, for their language" (from an unpublished manuscript). This attitude has largely influenced the position of all the employees of the structural typology department, which to this day remains unchanged.

4 The publication of the collection was resumed in 1998. After 2001, Maria V. Zavyalova became resp. Secretary of the Editorial Board. Currently, the chief editor of the collection (after the death of Viach.Vs. Ivanov in 2017) is V.A. Dybo.

5 At different times, the teachers of the Lithuanian language course at Moscow State University were also Tatiana V. Bulygina, Irina N. Toporova, Marina G. Netsetskaya.

6 The presentation which V.N. Toporov prepared for this conference, was later published as a separate book (Toporov 2001). 


\section{References}

Arkadiev, Peter \& Holvoet, Axel \& Wiemer, Björn (eds.) 2015. Contemporary Approaches to Baltic Linguistics. De Gruyter.

Arkadiev, Peter M. 2006. Tipologiya dvukhpadezhnyh sistem [Typology of Two-case Systems. Manuscript]. Moscow: Institute of Slavic Studies.

Budraitis, Juozas \& Nazarova, Evgeniya L. \& Zavyalova, Maria V. (eds.) 2007. Etnokul'turnye $i$ etnoyazykovye kontakty na territorii Vekikogo kniazhestva Litovskogo. Materialy mezhdunarodnoj konferencii [Ethnocultural and Ethnolinguistic Contacts in the Territory of the Grand Duchy of Lithuania. Proceedings of the international scientific conference]. Moscow: Novoe izdatel'stvo.

Bulygina, Tatiana V. 1970. Morfologicheskaya struktura slova v sovremennom litovskom yazyke (v ego pis'mennoj forme) [Morphological Structure of a Word in Modern Lithuanian Language (in its Written Form)] In: Viktor M. Zhirmunskij \& Nina D. Arutiunova (eds.) Morfologicheskaya struktura slova $v$ indoevropejskikh yazykakh [Morphological Structure of a Word in Indo-European Languages]. Moscow: Nauka, pp. 7-70.

Bulygina, Tatiana V. 1977. Problemy teorii morfologicheskikh modelej [Problems of the Theory of Morphological models]. Moscow: Nauka.

Dybo, Vladimir A. 1961. Sokrashchenie dolgot v kel'to-italijskikh yazykakh i ego znachenie dlia balto-slavianskoj i indoevropejskoj akcentologii [Quantity Reduction in Celtic-Italian Languages and its Significance for the Balto-Slavic and Indo-European Accentology]. Voprosy slavyanskogo yazykoznaniya [Issues of Slavic Linguistics], Vol. 5, pp. 9-34.

Dybo, Vladimir A. 1962. O rekonstruktsii udareniya v praslavyanskom glagole [On the Reconstruction of Stress in the pre-Slavic Verb]. Voprosy slavyanskogo yazykoznaniya [Issues of Slavic Linguistics], Vol. 6, pp. 3-27.

Illich-Svitych, Vladislav M. 1961. Vydelenie tipov korney s iskhodom na sonant $\mathrm{v}$ baltijskoj glagol'noj sisteme, ikh funkcionirovanie i proiskhozhdenie [Extraction of Root Types with an Outcome on Sonants in the Baltic Verb System, their Functioning and Origin]. Voprosy slavyanskogo yazykoznaniya [Issues of Slavic Linguistics], Vol. 5, pp. 108-137.

Illich-Svitych, Vladislav M. 1962. K istolkovaniyu aktsentuacionnykh sootvetstvij v kel'to-italijskom: o "vtorom pravile Dybo" [To the Interpretation of Accentuation Correspondences in Celtic-Italian and Balto-Slavic: about the "Second Rule of Dybo"]. Kratkie soobshcheniya Instituta slavyanovedeniya [Brief Communications of the Institute of Slavic Studies], Vol. 35, pp. 63-72. 
Illich-Svitych, Vladislav M. 1963. Imennaya akcentuaciya $v$ baltiyskom $i$ slavianskom (sud'ba akcentuacionnykh paradigm) [Noun Accentuation in the Baltic and Slavic (the Fate of Accentuation Paradigms)]. Moscow: Izdatel'stvo AN SSSR.

Ivanov, Viacheslav Vs. 1958. K etimologii baltijskogo i slavianskogo nazvanij boga groma [To the Etymology of the Baltic and Slavic Names of the God of Thunder]. Voprosy slavyanskogo yazykoznaniya [Issues of Slavic Linguistics], Vol. 3, pp. 101-111.

Ivanov, Viacheslav Vs. 1964. O proiskhozhdenii litovskikh pristavochnykh vozvratnykh glagol'nykh form [On the Origin of Lithuanian Prefixes for Reflexive Verb Forms]. Konferenciya po voprosam istorii baltijskikh yazykov [Conference on the History of the Baltic Languages]. Vilnius: Vilniusskiy gosudarstvennyj universitet.

Ivanov, Viacheslav Vs. 1981. Slavyanskij, baltiyskij i rannebalkanskij glagol. Indoevropejskie istoki [Slavic, Baltic and Early Balkan Verb. Indo-European Origins]. Moscow: Nauka.

Ivanov, Viacheslav Vs. (ed.) 1981. Balto-slavyanskie issledovaniya-1980 [Balto-Slavic Studies-1980]. Moscow: Nauka.

Ivanov, Viacheslav Vs. (ed.) 2010. La sémiotique contemporaine et les sciences humaines. Moscow: Yazyki slavianskikh kul'tur.

Ivanov, Viacheslav Vs. \& Nevskaya, Lidiya G. (eds.) 1990. Issledovaniya v oblasti baltoslavyanskoj dukhovnoj kul'tury: Pogrebal'nyj obryad [Studies in the Field of Balto-Slavic Spiritual Culture: Funeral Rite]. Moscow: Nauka.

Ivanov, Viacheslav Vs. \& Toporov, Vladimir N. 1958. Kpostanovke voprosa o drevnejshikh otnosheniyakh baltijskikh i slavianskikh yazykov [To the Question of the Oldest Relations of the Baltic and Slavic Languages]. Moscow: Izdatel'stvo AN SSSR.

Ivanov, Viacheslav Vs. \& Toporov, Vladimir N. 1965. Slavyanskie yazykovye modeliruyushchie semioticheskie sistemy (drevnij period) [Slavic Language Modeling Semiotic Systems (Ancient Period)]. Moscow: Nauka.

Judžentis, Artūras \& Tsivyan, Tatiana V. \& Zavjalova, Marija V. (eds.) 2014. Baltai ir slavai: dvasiniu kultūru sankirtos [Balts and Slavs: Intersections of Spiritual Cultures]. Vilnius: Versmè.

Kibrik, Andrey A. \& Toporov, Vladimir V. \& Zavyalova, Maria V. et al. (eds.) 2006. Yazyki mira: Baltijskiye yazyki [Languages of the World: Baltic Languages]. Moscow: Academia.

Kozhanov, Kirill A. 2015. Balto-slavyanskie areal'nye kontakty v oblasti glagol'noj prefiksacii Avtoreferat dissertacii na soiskanie stepeni kandidata filologicheskikh nauk [Balto-Slavic Areal Contacts in the Field of Verb Prefixation. Abstract of PhD theses]. Moscow: Institut slavianovedeniya RAN. 
Lomtev, Timofey P. 1948. Itogi diskussii po voprosam yazykovedeniya v svyazi s sessiej VASKHNIL [The Results of the Discussion on Linguistics in Connection with the Session of the Supreme Agricultural Academy]. Vestnik MGU [MSU Vestnik]. Dekabr'.

Miller, Vsevolod F. \& Fortunatov, Filipp F. 1873. Litovskie narodnye pesni, sobrannye V. Millerom i F. Fortunatovym [Lithuanian Folk Songs compiled by V. Miller and F. Fortunatov]. Moscow: Moskovskiy Universitet.

Nazarova, Evgeniya L. (ed.) 2007. Balty i Velikoe kniazhestvo Litovskoe: istoriko-lingvisticheskij vzgliad. Pamiati Egidijusa Banionisa [The Baltics and the Grand Duchy of Lithuania: a Historical-Linguistic View. In memory of Egidijus Banionis]. Moscow: Novoe izdatel'stvo.

Nevskaya, Lidiya G. 1977. Baltijskaya geograficheskaya terminologiya (k semanticheskoj tipologii) [Baltic Geographical Terminology (toward Semantic Typology)]. Moscow: Nauka.

Nevskaya, Lidiya G. \& Nikolaeva, Tatiana M. \& Sedakova, Irina A. \& Tsivyan, Tatiana V. 1998. Kontcept puti v fol'klornoy modeli mira (ot Baltii do Balkan) [The Concept of the Path in the Folklore Model of the World (from the Baltic to the Balkans)]. In: Oleg N. Trubachev (ed.) Slavyanskoe yazykoznanie. XII Mezhdunarodnyj s"ezd slavistov. Krakov, 1998 g. Doklady rossiyskoy delegacii [Slavic Linguistics. XII International Congress of Slavists. Krakow, 1998. Reports of the Russian Delegation]. Moscow: Nauka.

Nevskaya, Lidiya G. \& Sudnik, Tamara M. 1978. Dialektnye kontakty v zone sovremennogo baltijsko-slavyanskogo etnoyazykovogo pogranichya [Dialect Contacts in the Area of the Modern Balto-Slavic Ethno-lingual Frontier]. In: V.I. Borkovskyj et al. (eds.) Slavyanskoe yazykoznanie. VIII Mezhdunarodnyj s"ezd slavistov. Zagreb-Lyublyana, 1978 g. Doklady sovetskoy delegacii [Slavic Linguistics. VIII International Congress of Slavists. Zagreb-Ljubljana, 1978 Reports of the Soviet Delegation]. Moscow: Nauka, pp. 285-307.

Nikolaeva, Tatiana M. (ed.) 1993. Issledovaniya v oblasti balto-slavyanskoj dukhovnoj kul'tury: Zagovor [Studies in the Field of Balto-Slavic Spiritual Culture: Spell]. Moscow: Nauka.

Nikolaeva, Tatiana M. (ed.) 1994-1999. Issledovaniya v oblasti balto-slavyanskoj dukhovnoj kul'tury: Zagadka kak tekst [Studies in the Field of Balto-Slavic Spiritual Culture: A Riddle as a Text]. Moscow: Indrik, 1994, P. 1; 1999, P. 2.

Peterson, Mikhail N. 1946. Fortunatov i Moskovskaya lingvisticheskaya shkola [Fortunatov and Moscow Linguistic School]. Uchenye zapiski MGU. Vyp. 107. Rol' russkoj nauki v razvitii mirovoj nauki i kul'tury [Scientific Notes of Moscow State University. Issue 107. The Role of Russian Science in the Development of World Science and Culture]. Moscow: Vol. III, Book 2. 
Peterson, Mikhail N. 1948. Drevnejshij pamyatnik litovskogo yazyka [The Oldest Monument of the Lithuanian Language]. Vestnik MGU [MSU Vestnik], Vol. 3. Porzhezinsky, Viktor K. 1901. K istorii form spryazheniya $v$ baltijskikh yazykakh [On the History of Conjugation Forms in the Baltic Languages]. Moscow: Univ. Tip.

Porzhezinsky, Viktor K. 1903. Vozvratnaya forma glagolov v litovskom i latyshskom yazykakh. [The Reflexive Form of Verbs in Lithuanian and Latvian]. Moscow: Univ. Tip.

Stepanov, Yurij S. 1978. Slavyanskij glagol'nyj vid i baltijskaya diateza (problema obshchego genezisa i rekonstrukcii) [Slavic Verb Form and Baltic Diathesis (the Problem of General Genesis and Reconstruction)]. In: V.I. Borkovskyj et al. (eds.) Slavyanskoe yazykoznanie. VIII Mezhdunarodnyj s"ezd slavistov. Zagreb-Lyublyana, 1978 g. Doklady sovetskoy delegacii [Slavic Linguistics. VIII International Congress of Slavists. Zagreb-Ljubljana, 1978 Reports of the Soviet Delegation]. Moscow: Nauka, pp. 335-342.

Stepanov, Yurij S. 1972. Udarenie i metatoniya v litovskom glagole [Accent and Metatonia in the Lithuanian Verb]. Baltistica. Priedas 1.

Stepanov, Yurij S. 1976-1977. Vid, zalog, perekhodnost' (Balto-slavyanskaya problema) [Aspect, Voice, Transitivity (Balto-Slavic problem)]. Izvestiya AN SSSR. Ser. liter. $i$ yazyka [News of the USSR Academy of Sciences. Literature and Language Series]. 1976: Vol. 35, Iss. 5; 1977: Vol. 36, Iss. 2.

Stepanov, Yurij S. 1997. Neparadigmaticheskie peredvizheniya udareniya v indoevropejskom [Non-paradigmatic Movements of Stress in Indo-European]. Vestnik MGU. Ser. 9. Filologiya [MSU Vestnik. Series 9: Philology], Vol. 5.

Sudnik, Tamara M. 1975. Dialekty litovsko-slavyanskogo pogranich'ya. Ocherki fonologicheskikh sistem [Dialects of the Lithuanian-Slavic Borderland. Essays on Phonological Systems]. Moscow: Nauka.

Sudnik, Tamara M. \& Tolstaya, Svetlana M. \& Toporov, Vladimir N. 1967. K kharakteristike yuzhnoj chasti baltijsko-slavyanskogo yazykovogo soyuza [On the Characteristic of the Southern Part of the Balto-Slavic Language Union]. Sovetskoe slavyanovedenie [Soviet Slavic Studies], Vol. 2, pp. 38-47.

Sudnik, Tamara M. \& Tsivyan, Tatiana V. 1981. Mak v rastitel'nom kode osnovnogo mifa (Balto-Balcanica) [Poppy in the Vegetable Code of the Basic Myth (BaltoBalcanica)]. In: Ivanov, Viacheslav Vs. (ed.) Balto-slavyanskie issledovaniya-1980 [Balto-Slavic Studies-80]. Moscow: Nauka, pp. 300-317.

Sudnik, Tamara M., Tsivyan \& Tatiana V. 1982. O mifologii lyagushki: (balto-balkanskie dannye) [On Mythology of Frog: (Balto-Balkan data)]. In: Ivanov, Viacheslav Vs. (ed.) Balto-slavyanskie issledovaniya-1981 [Balto-Slavic Studies-1981]. Moscow: Nauka, pp. 137-154. 
Temchin, Sergey Yu. (ed.) 2005. Istoricheskij put' litovskoy pis'mennosti. Materialy konferencii [The Historical Path of Lithuanian Writing. Conference Proceedings]. Vilnius: Institut litovskogo yazyka.

Toporov, Vladimir N. 1958. Zametki po prusskoj etimologii [Notes on Prussian Etymology]. Voprosy slavyanskogo yazykoznaniya [Issues of Slavic Linguistics]. Vol. 3, pp. 112-119.

Toporov, Vladimir N. 1958a. Noveyshie raboty v oblasti izucheniya balto-slavyanskikh yazykovykh otnoshenij (Bibliograficheskij obzor) [Recent Works in the Field of the Study of Balto-Slavic Linguistic Relations (Bibliographic Review)]. Voprosy slavyanskogo yazykoznaniya [Issues of Slavic Linguistics], Vol. 3, pp. 134-151.

Toporov, Vladimir N. 1959. Ocherk istorii izucheniya drevnejshikh balto-slavyanskikh yazykovykh otnoshenij [Essay on the History of the Study of the Most Ancient Balto-Slavic Linguistic Relations]. Uchenye zapiski Instituta slavyanovedeniya [Scientific Notes of the Institute of Slavic Studies], Vol. 17, pp. 248-274.

Toporov, Vladimir N. 1961. K probleme balto-slavyanskikh yazykovykh otnoshenij (polozhenie del, zadachi) [On the Problem of Balto-Slavic Linguistic Relations (State of Matters, Tasks)]. Koordinacionnoe soveshchanie po aktual'nym problemam slavyanovedeniya. Programma soveshchaniya i tezisy dokladov [Coordination Meeting on Topical Problems of Slavic Studies. Meeting Program and Abstracts]. Moscow, pp. 64-69.

Toporov, Vladimir N. 1961a. K voprosu ob evolyutsii slavyanskogo i baltijskogo glagola [On the Evolution of the Slavic and Baltic Verbs]. Voprosy slavyanskogo yazykoznaniya [Issues of Slavic Linguistics], Vol. 5, pp. 35-70.

Toporov, Vladimir N. 1961b. K probleme balto-slavyaskikh yazykovykh otnoshenij [On the Problem of Balto-Slavic Linguistic Relations]. Kratkie soobshcheniya Instituta slavyanovedeniya [Brief Communications of the Institute of Slavic Studies], Iss. 33/34, pp. 211-218.

Toporov, Vladimir N. 1962. Iz istorii izucheniya drevnejshikh balto-slavyanskikh yazykovykh otnoshenij [From the History of the Study of the Most Ancient Balto-Slavic Linguistic Relations]. Uchenye zapiski Instituta slavyanovedeniya [Scientific Notes of the Institute of Slavic Studies]. Vol. 23, pp. 3-43.

Toporov, Vladimir N. 1975-1990. Prusskiy yazyk: Slovar' [Prussian Language: Dictionary]. Moscow: 1975, T. 1: (A-D); 1979, T. 2: (E-H); 1980, T. 3: (I-K); 1984, T. 4: (K-L); 1990, T. 5: (L).

Toporov, Vladimir N. 1982. Drevnyaya Moskva v baltijskoj perspektive [Ancient Moscow in the Baltic Perspective]. In: Ivanov, Viacheslav Vs. (ed.) Balto-slavyanskie issledovaniya-81 [Balto-Slavic Studies-81]. Moscow: Nauka, pp. 3-61. 
Toporov, Vladimir N. 1988. Baltijskij element v gidronimii Pooch'ya. I [The Baltic Element in the Hydronymy of Oka District. I]. In: Ivanov, Viacheslav Vs. (ed.) Balto-slavyanskie issledovaniya-86 [Balto-Slavic Studies-86]. Moscow: Nauka, pp. 154-177.

Toporov, Vladimir N. 1989. Baltijskij element v gidronimii Poochya. II [The Baltic Element in the Hydronymy of Oka District. II]. In: Ivanov, Viacheslav Vs. (ed.) Balto-slavyanskie issledovaniya-87 [Balto-Slavic Studies-87]. Moscow: Nauka, pp. 47-69.

Toporov, Vladimir N. 2001. Nachalo litovskoy pis'mennosti: Martinas Mazhvidas v kontekste ego vremeni (K 450-letiyu so dnya vykhoda v svet pervoj litovskoj knigi) [The Beginning of Lithuanian Writing: Martinas Mazhvidas in the Context of his Time (On the $450^{\text {th }}$ Anniversary of the Publication of the First Lithuanian Book)]. Vilnius-Moscow: Baltos lankos.

Toporov, Vladimir N. \& Trubachev, Oleg N. 1962. Lingvisticheskij analiz gidronimov Verkhnego Podneprov'ya [Linguistic Analysis of Hydronyms of the Upper Dnieper]. Moscow: Izdatel'stvo AN SSSR.

Tsivyan, Tatiana V. 1989. Zametki po balto-balkanskomu mifologicheskomu gerbariyu: ruta [Notes on the Baltic-Balkan Mythological Herbarium: Ruta]. In: Ivanov, Viacheslav Vs. (ed.) Balto-slavyanskie issledovaniya-1987 [Balto-Slavic Studies-1987]. Moscow: Nauka, pp. 69-72.

Tsivyan, Tatiana V. \& Zavyalova, Maria V. (eds.) 2010. Toporovskie chteniya I-IV (2006-2009). Izbrannoe. [Toporov Readings I-IV (2006-2009). Selected Articles]. Moscow: Probel.

Zavyalova, Maria V. 2006. Balto-slavyanskij zagovornyj tekst: lingvisticheskij analiz $i$ kartina mira [Balto-Slavic Text of Spell: Linguistic Analysis and Picture of the World]. Moscow: Nauka.

Zinkevichus, Zigmas 1984. Pol'sko-yatvyazhskij slovarik [Polish-Yatvyaz Dictionary]. In: Ivanov, Viacheslav Vs. (ed.) Balto-slavyanskie issledovaniya-1983. [Balto-Slavic Studies-1983] Moscow: Nauka, pp. 3-29.

Maria Zavyalova, PhD in Philology, Senior Researcher at the Department of Typology and Comparative Linguistics, Center for Balto-Slavic Studies, Institute of Slavic Studies, Russian Academy of Sciences, Moscow, Russia. Her research interests are in the field of Balto-Slavic linguistic and ethnocultural contacts, Slavic and Baltic languages, folklore, ethnolinguistics, psycholinguistics, semiotics. 